\title{
Intraoperative Frozen Section in Uropathology: When and How?
}

\author{
Üropatolojide Intraoperatif Frozen Inceleme: Ne Zaman ve Nası?
}

\author{
Yelda Dere \\ Muğla Sıtkı Koçman University Faculty of Medicine, Department of Pathology, Muğla, Turkiye
}

\section{Introduction}

Frozen section, which is also known as intraoperative pathology consultation, is one of the most challenging expertise of surgical pathology practice due to many reasons, such as inadequate sampling, freezing artefacts on the tissue section and necessity of quick decision due to the limitation of time, and is being used in many surgical operations in order to choose the right procedure for the patients $(1,2)$. The surgeons should share the patient's clinical data with the pathologist for the method to be successful and specify the expectations from the pathologist for choosing the most appropriate treatment option (1). In addition, both the surgeon and the pathologist must know the advantages and the limitations of the frozen section, specify the indications and act between these limits.

\section{Frozen Section in Genitourinary Pathology}

Various indications and problems associated with the frozen section can be counted in every organ-specific disease in genitourinary system pathology and, some of them are summarized as follows:

\section{Evaluation of the Surgical Margins}

a) Frozen section is generallystudied during radical prostatectomy (RP) in high-risk patients (high biopsy Gleason score and high prostate-specific antigen level), especially when nerve sparing or robotic surgery is being used $(2,3)$. The most conflicting artefacts are crushed tissues, cauterization and heat artefacts as well as freezing artefacts. In such conditions, deeper sections or additional tissue fragments may be needed due to difficulty in assessing small carcinomatous glands, nucleolar prominence and myoepithelial layer. If the suspicion for margin positivity continues, even if many sections were cut and additional tissue fragments were sectioned, the margin status can be given by observing the permanent paraffin blocks (2).

b) As the indications of partial nephrectomy widen, the evaluation of the surgical margins in partial nephrectomies became the most common indication of the frozen section in renal tumors (4). Two types of tissues can be sent for frozen section analysis. The surgeon may send a small fragment of tumor bed parenchyma which can be fully assessed for frozen section or the whole partial nephrectomy specimen. When the whole specimen is sent, the surgeon must ink the parenchyma side of the surgical margin in order to preserve its orientation (5). However, as most of the tumors treated with partial nephrectomy are well defined or capsulated, many authors stated that the macroscopic view of the surgeon is generally accepted enough for the evaluation of the margins without frozen section (6).

c) The evaluation of the surgical margins of the ureters and urethra during radical cystectomy is the most common frozen section study among all genitourinary pathologies $(2,7)$. In frozen section, reporting mild and moderate dysplasia should be avoided as they have no clinical. However, reporting the presence of high grade dysplasia or carcinoma in situ is important depending on the necessity of additional marginal excision. The rate of high grade dysplasia or carcinoma in situ in ureteral margins has been reported to be $4.8-9 \%$ in the literature (8). Diagnosis based on frozen section can be difficult depending on the effects of applied treatments, cauterization or freezing artefacts (Figure 1, 2). In addition, pathologists should always keep in mind that the reactive urothelium can show atypical cellular morphology and search additional features such as loss of polarity, nuclear hyperchromasia and high nucleus/ cytoplasmic ratio before diagnosing dysplasia.

Correspondence: Yelda Dere MD, Muğla Sıtkı Koçman University Faculty of Medicine, Department of Pathology, Muğla, Turkiye

Phone: +90 5323122377 E-mail: yeldamorgul@gmail.com ORCID-ID: orcid.org/0000-0003-0238-2236

Received: 02.08 .2017

Accepted: 16.08.2017

Cite this article as: Dere Y. Intraoperative Frozen Section in Uropathology: When and How? J Urol Surg 2017;4:156-158.

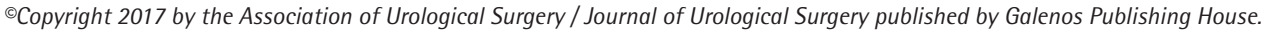


d) In testicular tumors, evaluation of surgical margins is a very rare indication which is only used in testis sparing surgical procedures (7).

e) Evaluation of surgical margins is the most common indication for frozen section in penile surgeries (7). The urethral margin sent for frozen section analysis should include corpus spongiosum, corpus cavernosa, penile fascia and the skin and the distal margin should be inked by the surgeon in order to orientate the pathologist (7). When the whole penectomy specimen is sent for frozen section, the pathologist must be sure that the proximal surgical margin is located upright in the frozen section.

\section{The Diagnosis of the Tumor and Tumor Type}

a) There are no indications for frozen section during RP, radical cystectomy or penectomy for the diagnosis of the tumor as they are generally diagnosed by transurethral needle biopsies,

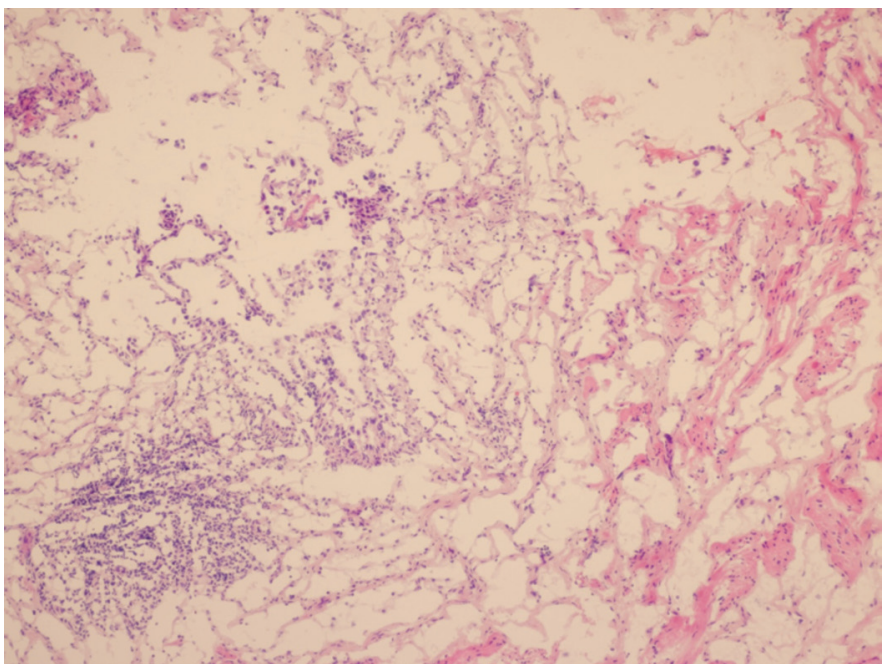

Figure 1. Frozen section of ureter with fragmentation and freezing artefacts which has given a frozen diagnosis of carcinoma in situ, hematoxylin and eosin, $\times 100$

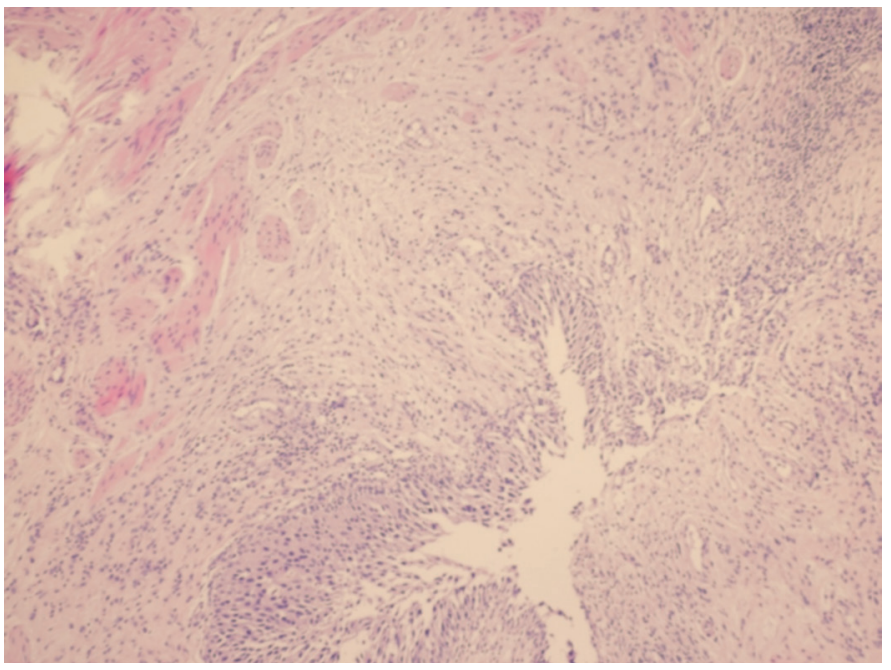

Figure 2. Permanent paraffin section of the same ureter, hematoxylin and eosin, $x 100$ resections or incisional biopsies $(2,7,9)$.

b) The histological type of renal tumors is the rarest indication of frozen section which rarely affects the surgical operation. Although for tumors with specific morphologic features can be diagnosed easily, oncocytic or cystic changes, papillary growth pattern, angiomyolipomas with low fat configuration, and high grade tumors may complicate the diagnostic approach (2). Additionally, it is important to make differential diagnosis between renal cell tumors and urothelial carcinoma because of the necessity of ureterectomy during surgical procedure.

c) The type of testicular malignant germ cell tumors has no effect on the type of surgical procedure, thus there is no indication for frozen section (1). However, in some testicular and most paratesticular lesions, frozen section is important in order to ensure the testis sparing surgery. Prepubertal age,

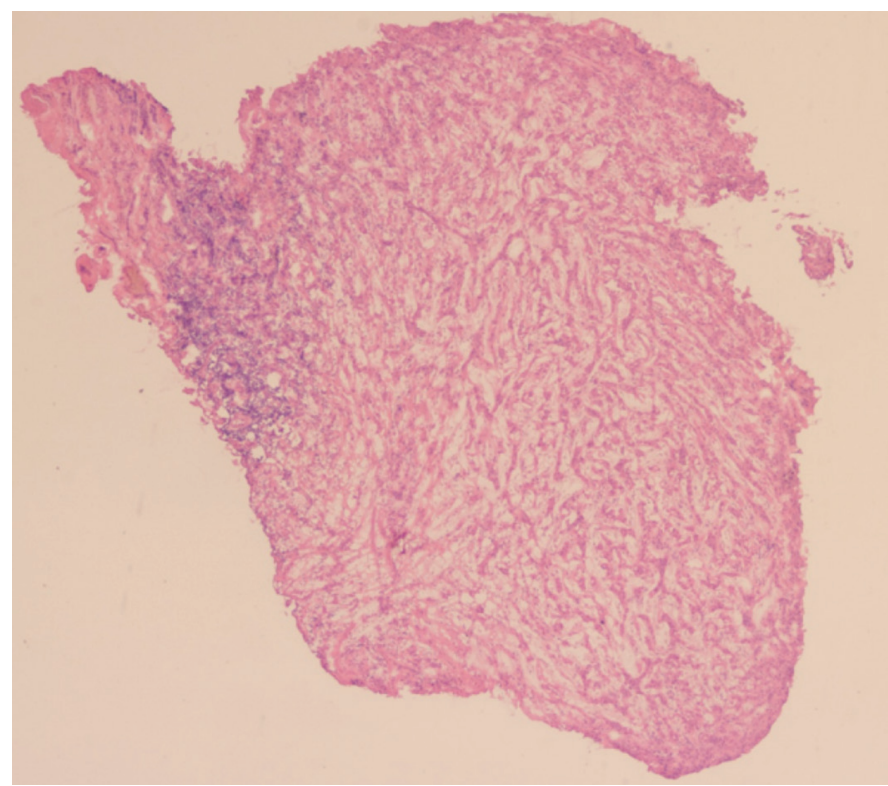

Figure 3. Frozen section of a paratesticular tumor: the patient was given a frozen diagnosis concordant with adenomatoid tumor and operated by partial orchiectomy, hematoxylin and eosin, $x 40$

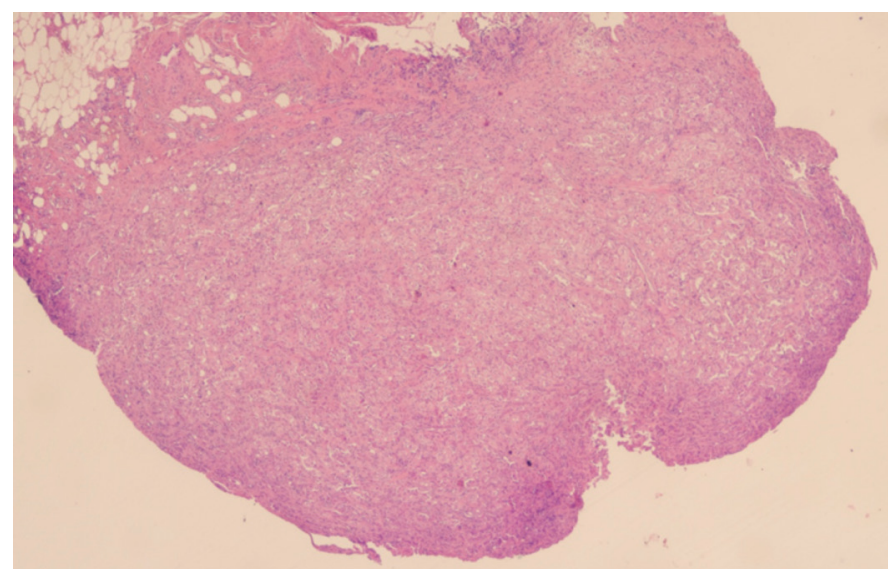

Figure 4. Permanent paraffin section of the same case with the final diagnosis of adenomatoid tumor, hematoxylin and eosin, $x 40$ 
inflammatory or infectious nonneoplastic lesions (such as sperm granuloma) and benign neoplastic lesions (such as adenomatoid tumor, lipoma) need frozen section for preventing redundant orchiectomies (Figure 3, 4) $(2,7)$.

\section{The Evaluation of Lymph Nodes}

Frozen sections of the lymph nodes are studied by the same procedure in all genitourinary malignancies. The lymph nodes are macroscopically examined first and the suspicious cut surface is being sectioned for microscopic evaluation regardless of the primary malignancy (2). The specificity of frozen section diagnosis of the lymph nodes has been reported to be very high in many studies (10). However, the adipose tissue replacing the lymph node in older patients and the difficulty in freezing and sectioning adipose tissue must be considered in false negativity which has been reported to be as high as 33\% in RPs (10).

In conclusion, frozen section study has many advantages and limitations in uropathology as in other systems. Thus, pathologists and urologists must be aware of the exact indications and the limitations of the frozen section.

Keywords: Frozen section, intraoperative consultation, uropathology

Anahtar Kelimeler: Frozen inceleme, intraoperatif konsültasyon, üropatoloji

\section{Acknowledgements}

Special thanks to Prof. Dr. Kutsal Yörükoğlu for the figures.

\section{Ethics}

Peer-review: Internally peer-reviewed.

Financial Disclosure: The author declared that this study received no financial support.

\section{References}

1. Hekimgil M. Frozen inceleme: Tarihçe, teknik ve kalite güvencesi in Biyopsilerin yorumu: Frozen inceleme, 1st ed, 2015, pp. 1-15.

2. Shen $S S$, Truong $L D$, Ro JY, Ayala AG. Use of frozen section in genitourinary pathology. Pathology 2012;44:427-433.

3. Algaba F, Arce Y, Lopez-Beltran A, Montironi R, Mikuz G, Bono AV; European Society of Uropathology; Uropathology Working Group. Intraoperative frozen section diagnosis in urological oncology. Eur Urol 2005;47:129-136.

4. Bensalah K, Pantuck AJ, Rioux-Leclercq N, Thuret R, Montorsi F, Karakiewicz Pl, Mottet N, Zini L, Bertini R, Salomon L, Villers A, Soulie M, Bellec L, Rischmann $\mathrm{P}$, De la Taille A, Avakian R, Crepel M, Ferriere JM, Bernhard JC, Dujardin T, Pouliot F, Rigaud J, Pfister C, Albouy B, Guy L, Joniau S, van Poppel H, Lebret T, Culty T, Saint F, Zisman A, Raz O, Lang H, Spie R, Wille A, Roigas J, Aguilera A, Rambeaud B, Martinez Piñeiro L, Nativ O, Farfara R, Richard F, Roupret M, Doehn C, Bastian PJ, Muller SC, Tostain J, Belldegrun AS, Patard JJ. Positive surgical margin appears to have negligible impact on survival of renal cell carcinomas treated by nephron-sparing surgery. Eur Urol 2010;57:466-471.

5. Algaba F, Trias I, Scarpelli M, Boccon-Gibod L, Kirkali Z, Van Poppel H. Handling and pathology reporting of renal tumor specimens. Eur Urol 2004;45:437-443.

6. Timsit MO, Bazin JP, Thiounn N, Fontaine E, Chrétien Y, Dufour B, Mejean A. Prospective study of safety margins in partial nephrectomy: intraoperative assessment and contribution of frozen section analysis. Urology 2006;67:923-926.

7. Yörükoğlu K, Tuna B. Genitoüriner sistem in Biyopsilerin yorumu: Frozen inceleme, 1st ed, 2015, pp. 164-210.

8. Lebret T, Hervé JM, Barré P, Gaudez F, Lugagne PM, Barbagelatta M, Botto $H$. Urethral recurrence of transitional cell carcinoma of the bladder. Predictive value of preoperative latero-montanal biopsies and urethral frozen sections during prostatocystectomy. Eur Urol 1998;33:170-174.

9. Pizzocaro $G$, Algaba $F$, Horenblas $S$, Solsona $E$, Tana $S$, Van Der Poel $H_{\text {, }}$ Watkin NA; European Association of Urology (EAU) Guidelines Group on Penile Cancer. EAU penile cancer guidelines 2009. Eur Urol 2010;57:10021012.

10. Davis GL. Sensitivity of frozen section examination of pelvic lymph nodes for metastatic prostate carcinoma Cancer 1995;76:661-668. 